\title{
SÚMULA: POLÍTICA NACIONAL DE EDUCAÇÃO ESPECIAL NA PERSPECTIVA DA EDUCAÇÅ̉O INCLUSIVA
}

$\mathcal{E}$

ste documento foi elaborado pela equipe da Secretaria de Educação Especial do Ministério da Educação e pesquisadores da área. Em janeiro de 2008 foi entregue ao Ministro da Educação.

Esta súmula apresenta recortes do documento original, que pode ser consultado na íntegra no site <www.mec.gov.br>.

\section{I - Apresentação}

O movimento mundial pela inclusão é uma ação política, cultural, social e pedagógica, desencadeada em defesa do direito de todos os alunos de estarem juntos, aprendendo e participando, sem nenhum tipo de discriminação. A educação inclusiva constitui um paradigma educacional fundamentado na concepção de direitos humanos, que conjuga igualdade e diferença como valores indissociáveis, e que avança em relação à idéia de eqüidade formal ao contextualizar as circunstâncias históricas da produção da exclusão dentro e fora da escola.

Nesta perspectiva, o Ministério da Educação/Secretaria de Educação Especial apresenta a Política Nacional de Educação Especial na Perspectiva da Educação Inclusiva, que acompanha os avanços do conhecimento e das lutas sociais, visando constituir políticas públicas promotoras de uma educação de qualidade para todos os alunos.

\section{II - Marcos históricos e normativos}

A escola, historicamente, se caracterizou pela visão da educação que delimita a escolarização como privilégio de um grupo, uma exclusão que foi legitimada nas políticas e práticas educacionais reprodutoras da 
ordem social. A partir do processo de democratização da educação se evidencia o paradoxo inclusão/exclusão, quando os sistemas de ensino universalizam o acesso, mas continuam excluindo indivíduos e grupos considerados fora dos padrões homogeneizadores da escola. Assim, sob formas distintas, a exclusão tem apresentado características comuns nos processos de segregação e integração que pressupõem a seleção, naturalizando o fracasso escolar.

A partir da visão dos direitos humanos e do conceito de cidadania fundamentado no reconhecimento das diferenças e na participação dos sujeitos, decorre uma identificação dos mecanismos e processos de hierarquização que operam na regulação e produção das desigualdades. Essa problematização explicita os processos normativos de distinção dos alunos em razão de características intelectuais, físicas, culturais, sociais e lingüísticas, entre outras, estruturantes do modelo tradicional de educação escolar.

A educação especial se organizou tradicionalmente como atendimento educacional especializado substitutivo ao ensino comum, evidenciando diferentes compreensões, terminologias e modalidades que levaram a criação de instituições especializadas, escolas especiais e classes especiais. Essa organização, fundamentada no conceito de normalidade/ anormalidade, determina formas de atendimento clínico-terapêuticos fortemente ancorados nos testes psicométricos que definem, por meio de diagnósticos, as práticas escolares para os alunos com deficiência.

A Constituição Federal de 1988 traz, como um dos seus objetivos fundamentais, "promover o bem de todos, sem preconceitos de origem, raça, sexo, cor, idade e quaisquer outras formas de discriminação" (art. $3^{\circ}$, inciso IV). Define, no artigo 205, a educação como um direito de todos, garantindo o pleno desenvolvimento da pessoa, o exercício da cidadania e a qualificação para o trabalho. No seu artigo 206, inciso I, estabelece a "igualdade de condições de acesso e permanência na escola", como um dos princípios para o ensino, e garante, como dever do Estado, a oferta do atendimento educacional especializado, preferencialmente na rede regular de ensino (art. 208).

\section{III - Diagnóstico da educação especial}

O Censo Escolar/MEc/InEP, realizado anualmente em todas as escolas de educação básica, acompanha, na educação especial, indicadores 
de acesso à educação básica, matrícula na rede pública, inclusão nas classes comuns, oferta do atendimento educacional especializado, acessibilidade nos prédios escolares e o número de municípios e de escolas com matrícula de alunos com necessidades educacionais especiais.

A evolução das ações da educação especial nos últimos anos se expressa no crescimento do número de municípios com matrículas, que em 1998 registra 2.738 municípios $(49,7 \%)$ e, em 2006 alcança 4.953 municípios $(89 \%)$, um crescimento de $81 \%$. Essa evolução também revela o aumento do número de escolas com matrícula, que em 1998 registra apenas 6.557 escolas e chega a 54.412 escolas em 2006, representando um crescimento de $730 \%$. Destas escolas com matrícula em 2006, 2.724 são escolas especiais, 4.325 são escolas comuns com classe especial e 50.259 são escolas comuns com inclusão nas turmas de ensino regular.

Em relação à formação dos professores com atuação na educação especial, em 1998, 3,2\% possuíam ensino fundamental; 51\% possuíam ensino médio e 45,7\% ensino superior. Em 2006, dos 54.625 professores que atuam na educação especial, 0,62\% registraram somente ensino fundamental, $24 \%$ registraram ensino médio e $75,2 \%$ ensino superior. Nesse mesmo ano, 77,8\% destes professores, declararam ter curso específico nessa área de conhecimento.

\section{IV - Objetivo da Política Nacional de Educação Especial na Pers-} pectiva da Educação Inclusiva

A Política Nacional de Educação Especial na Perspectiva da Educação Inclusiva tem como objetivo assegurar a inclusão escolar de alunos com deficiência, transtornos globais do desenvolvimento e altas habilidades/ superdotação, orientando os sistemas de ensino para garantir: acesso ao ensino regular, com participação, aprendizagem e continuidade nos níveis mais elevados do ensino; transversalidade da modalidade de educação especial desde a educação infantil até a educação superior; oferta do atendimento educacional especializado; formação de professores para o atendimento educacional especializado e demais profissionais da educação para a inclusão; participação da família e da comunidade; acessibilidade arquitetônica, nos transportes, nos mobiliários, nas comunicações e informação; e articulação intersetorial na implementação das políticas públicas. 


\section{V - Alunos atendidos pela educação especial}

$\mathrm{Na}$ perspectiva da educação inclusiva, a educação especial passa a constituir a proposta pedagógica da escola, definindo como seu públicoalvo os alunos com deficiência, transtornos globais de desenvolvimento e altas habilidades/superdotação. Nestes casos e outros, que implicam transtornos funcionais específicos, a educação especial atua de forma articulada com o ensino comum, orientando para o atendimento às necessidades educacionais especiais desses alunos.

Consideram-se alunos com deficiência aqueles que têm impedimentos de longo prazo, de natureza física, mental, intelectual ou sensorial, que em interação com diversas barreiras podem ter restringida sua participação plena e efetiva na escola e na sociedade. Os alunos com transtornos globais do desenvolvimento são aqueles que apresentam alteraçôes qualitativas das interaçôes sociais recíprocas e na comunicação, um repertório de interesses e atividades restrito, estereotipado e repetitivo. Incluem-se nesse grupo alunos com autismo, síndromes do espectro do autismo e psicose infantil. Alunos com altas habilidades/superdotação demonstram potencial elevado em qualquer uma das seguintes áreas, isoladas ou combinadas: intelectual, acadêmica, liderança, psicomotricidade e artes. Também apresentam elevada criatividade, grande envolvimento na aprendizagem e realização de tarefas em áreas de seu interesse. Dentre os transtornos funcionais específicos estão: dislexia, disortografia, disgrafia, discalculia, transtorno de atenção e hiperatividade, entre outros.

\section{VI - Diretrizes da Política Nacional de Educação Especial na Pers- pectiva da Educação Inclusiva}

A educação especial é uma modalidade de ensino que perpassa todos os níveis, etapas e modalidades, realiza o atendimento educacional especializado, disponibiliza os serviços e recursos próprios desse atendimento e orienta os alunos e seus professores quanto a sua utilização nas turmas comuns do ensino regular.

$\mathrm{O}$ atendimento educacional especializado identifica, elabora e organiza recursos pedagógicos e de acessibilidade que eliminem as barreiras para a plena participação dos alunos, considerando as suas necessidades específicas. As atividades desenvolvidas no atendimento educacional especializado diferenciam-se daquelas realizadas na sala de 
aula comum, não sendo substitutivas à escolarização. Esse atendimento complementa e/ou suplementa a formação dos alunos com vistas à autonomia e independência na escola e fora dela.

$\mathrm{O}$ atendimento educacional especializado disponibiliza programas de enriquecimento curricular, o ensino de linguagens e códigos específicos de comunicação e sinalização, ajudas técnicas e tecnologia assistiva, dentre outros. Ao longo de todo processo de escolarização, esse atendimento deve estar articulado com a proposta pedagógica do ensino comum.

Para atuar na educação especial, o professor deve ter como base da sua formação, inicial e continuada, conhecimentos gerais para o exercício da docência e conhecimentos específicos da área. Essa formação possibilita a sua atuação no atendimento educacional especializado e deve aprofundar o caráter interativo e interdisciplinar da atuação nas salas comuns do ensino regular, nas salas de recursos, nos centros de atendimento educacional especializado, nos núcleos de acessibilidade das instituições de educação superior, nas classes hospitalares e nos ambientes domiciliares, para a oferta dos serviços e recursos de educação especial.

Essa formação deve contemplar conhecimentos de gestão de sistema educacional inclusivo, tendo em vista o desenvolvimento de projetos em parceria com outras áreas, visando à acessibilidade arquitetônica, aos atendimentos de saúde, à promoção de ações de assistência social, trabalho e justiça. 